\title{
Implementering af e-læring ved danske universiteter
}

\section{- tværsnitsundersøgelse efteråret 2005}

\section{Jens Dørup}

E-læringsenheden

Aarhus Universitet

\section{Jørgen Gomme}

Institut for Molekylær Biologi og Fysiologi

Københavns Universitet

\section{Ambrosia Hansen \\ HR-udvikling, e-læring \\ Syddansk Universitet}
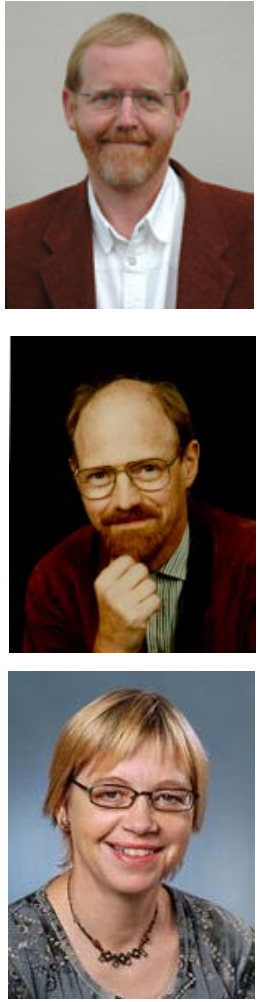

\author{
Birgitte Heiberg \\ CBS Learning Lab \\ Copenhagen Business School
}

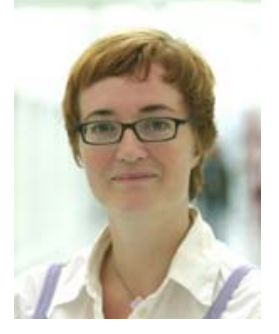

Jens Dørup er leder af Aarhus Universitets e-lceringsenhed (se http://www.iktlab.au.dk og http://www.e-learning.au.dk) og af Sektionen for Sundhedsinformatik, Institut for Folkesundhed, Aarhus Universitet; næestformand for Dansk Selskab for Medicinsk Uddannelse; bestyrelsesmedlem i Society for the Internet in Medicine), og bestyrelsesmedlem i EUNIS (European University Information Systems). Medlem af UNEVs ekspertgruppe.

Jørgen Gomme er lektor ved Institut for Molekylær Biologi og Fysiologi ved Københavns Universitet, og tidligere direktør for Naturvidenskabeligt IT-Kompetencecenter (NIK); har veret formand for Københavns Universitets arbejdsgruppe vedr. Web-based Learning (WBL); medlem af UNEVs ekspertgruppe; formand for Forskningsnettets Video-erfagruppe.

Ambrosia Hansen er e-leringskoordinator ved Syddansk Universitet, hvor hun arbejder med udvikling og koordinering af universitetets e-laringsinitiativer, samt deltager såvel interne som eksterne netvcerk om udvikling af e-lcering.

Birgitte Heiberg er projektchef på CBS Learning Lab og varetager projekter og konsulentbistand omkring e-læring, udvikling og afholdelse af kurser for undervisere, udvikling af koncepter for netstøttet undervisning, samt udvikling af det fysiske leringsmiljø i CBS-bygninger. Medlem af UNEVs ekspertgruppe. 


\section{Indledning}

Lige siden de første computere kom til landet har der været projekter, som tilsigtede at understøtte undervisning og læring ved hjælp af IKT. Understøttelsen har varieret som en bred vifte af forskellige former for medieanvendelse og grader af interaktion. Tilsvarende er diverse former for IKT-støttet undervisning og læring med forskellige betegnelser dukket op: Computer-Based Training (CBT), Computer Assisted Learning (CAL), Computer Supported Collaborative Learning (CSCL), Web-based Learning (WBL), blended learning, online læring, fleksibel læring, fjernundervisning, distribueret og åben uddannelse, m. fl.

Søren Nipper fra UNI-C anfører, at online læring kom til Danmark i 1982, men at det frem til 1998 stort set lå i dvale (Nipper, S. side 215 i (Paulsen, 2003)). Efter 1998 har udviklingen dog taget fart, og fra en start med anvendelser som mest var i forbindelse med åben uddannelse, er e-læring nu for alvor blevet en central faktor på universiteterne.

Danske universiteter har en lang tradition for, at lærerne på selvstændig vis tilrettelægger både undervisningens form og indhold, samt evaluering og eksamen. Dette har gennem årene medført stor diversitet i den måde hvorpå kurser udbydes, afvikles og evalueres - både imellem universiteterne, men også internt på de enkelte universiteter. Dette gælder både for den traditionelle undervisning og e-læring. De seneste 5-10 år er der dog sket en udvikling i retning af at koordinere den basale IKT-støtte af undervisningen fra centralt hold, typisk således, at man har tilstræbt integration af e-læringssystemerne med de eksisterende IKT-systemer til administration af personale, studenter, kurser og lokaler. Som sådan kan en centralisering i driften af e-læringssystemerne ses som et skridt imod en ensretning, hvilket både kan åbne for nye muligheder og skabe problemer.

Graden af forskellighed i tilgangen til e-læring, variationen i de strategiske overvejelser og måden hvorpå e-læringsbeslutninger træffes på danske universiteter, er dog stort set ukendt. Da universiteternes efter og -videreuddannelsesportal, www.unev.dk, i foråret 2005 besluttede at invitere til et tema om strategier for implementering af e-læring på danske universiteter, fandt redaktionsgruppen (som repræsenterer 4 universiteter), at det ville være interessant at foretage en undersøgelse af e-læringsstrategier og -politikker ved de 12 danske universiteter. Hovedformålet var at få afklaret, i hvilken udstrækning og på hvilken måde e-læringsplatforme ${ }^{1}$ benyttes ved undervisning og læring på universiteterne. Hvilket samspil har disse platforme med den øvrige, hovedsageligt campus-baserede undervisning? Hvilke platforme er i spil? Hvilken forståelse for e-læring har de personer, som på de respektive universiteter arbejder med e-læring som ansvarsområde? Hvordan er balancen mellem en hovedsagelig campus-baseret undervisning med hjælp af e-læring på den ene side og en hovedsagelig IKTunderstøttet fjernundervisning på den anden, og er der fællestræk ved sammenligning mellem universiteterne? Vi var interesserede i at tegne et samlet billede af e-læringen, således at man på de enkelte universiteter kunne sætte den lokale udvikling i perspektiv i forhold til den nationale og internationale.

Denne artikel præsenterer undersøgelsens resultater i kort form. Der tegnes et billede af en udstrakt og fremadskridende anvendelse af e-læringsredskaber på danske universiteter - men med store forskelle mellem de enkelte institutioner og fag. De organisatoriske rammer omkring implementering af e-læring, og dennes evt. tilknytning til en overordnet institutionsbaseret strategi på e-læringsområdet beskrives.

\footnotetext{
${ }^{1}$ En e-læringsplatform forstås her som et samlet system til at understøtte kurser, undervisning og læring, stort set synonymt med det engelske Learning Management System (LMS).
} 


\section{Materiale og metoder}

Spørgeskemaet, som har været anvendt i undersøgelsen², er en videreudvikling af et skema som parallelt med den danske anvendelse er blevet brugt i et europæisk projekt i regi af EUNIS (European University Information Systems, www.eunis.org). Denne organisation har etableret en e-learning task force med henblik på at undersøge tendenser i e-læringen på europæiske universiteter. Et pilotskema blev fremstillet i foråret 2005 og en videre udvikling skete på EUNIS’ kongres i Manchester i juni 2005, hvor ca. 30 e-læringsinteresserede fra europæiske universiteter bidrog med forslag til skemaet. Målet var at inddrage forhold, som deltagerne gerne selv så belyst fra andre universiteter. Udviklingen af skemaet med tilføjelsen af flere spørgsmål, som vi i Danmark fandt særligt interessante, foregik herefter i sommeren og efteråret 2005 imellem de 4 forfattere af denne artikel.

Spørgeskemaet blev implementeret ved hjælp af Macromedia ColdFusion MX version 6.1 (www.macromedia.com/coldfusion) på en Microsoft Windows 2003 server. Macromedia Dreamweaver blev brugt til fremstilling af ColdFusion scriptet, som kommunikerede med en Access database.

Spørgeskemaet blev stilet til e-læringssansvarlige enten på centralt, fakultært eller institutniveau, idet disse første kontakter dog blev anmodet om at videresende link til spørgeskemaet til andre e-læringsansvarlige på deres institution. Vi modtog svar fra 20 personer, som repræsenterede alle 12 universiteter. Respondenternes tilhørsforhold og administrative forankring varierer fra universitet til universitet, bl.a. fordi der ikke findes en ensartet organisering på danske universiteter. Dette forhold repræsenterer en mulig fejlkilde i forhold til fortolkningen af resultaterne.

\section{Resultater}

\section{Definitioner af e-læring}

E-læring er i litteraturen og på internettet ikke entydigt defineret. En Google-søgning (november 2005) på what is e-learning giver således 15 definitioner med både lighedspunkter og forskelle. En diskussion af definitionen kan også findes i (Piskurich, 2003) hvor det ligeledes konkluderes, at der er stor forskel på hvorledes begrebet e-læring opfattes. Som et centralt punkt i spørgeskemaet spurgte vi derfor om, hvordan den enkelte respondent definerer elæring. De mange forskellige måder at definere og afgrænse e-læring på afspejler sig i undersøgelsens svar, der i grove træk kan opdeles i fire kategorier:

1. En generel eller åben definition, der formentlig er valgt bevidst for ikke at udelukke nogen, og som danner baggrund for udvikling og implementering inden for vide rammer:

- Alle former for IKT-støttet undervisning.

2. En definition, der hovedsageligt baseres på en organisatorisk tilgang: Her understreges e-læring som et instrument til at fremstille, organisere og distribuere undervisningsmateriale, til at lette den praktiske administration af et studie- eller kursusforløb, eller som en hjælp til de studerende til at danne sig overblik over et fagområde:

- Undervisning, hvor laringsmuligheder organiseres helt eller delvist via digitale medier til de studerende.

\footnotetext{
${ }^{2}$ Skemaet findes på http://www.video.au.dk/cf/unev6.cfm.
} 
- Inddragelsen af IKT-baserede redskaber til støtte for tilrettelceggelse af undervisning og uddannelse.

- Hjcelp til at finde strukturen i et undervisningsforløb.

3. En teknisk-prceget definition, der tager udgangspunkt i de systemer, der anvendes til elæring:

- Al undervisning, der er IKT-støttet.

- Brug af en fcelles hjemmeside i undervisningen.

4. En pæedagogisk/didaktisk-præget definition, der tager udgangspunkt i processer, der fremmer den studerendes individuelle læring:

- Støtte til undervisning og læring i form af materialer og kommunikation med mennesker.

- Anvendelse af IKT til at fremme et pæedagogisk-didaktisk mål i undervisningen.

- Skabelse af et rigt lceringsmiljø, der giver adgang for en aktiv konstruktionsproces for den enkelte studerende i samspil med de sociale omgivelser.

- Indbyder til og muliggør øget refleksion, samarbejde og projektarbejde, diskussion, case studies, aktivering af de studerende.

- Eller blot: Lcereprocesser, som er medierede af IKT.

Selvom forskellige læringsteorier kan skinne igennem beskrivelserne, afspejler de forskellige definitioner ikke nødvendigvis et forskelligt grundlæggende syn på læring eller e-læring. De kan derimod til en vis grad afspejle de erfaringer eller den konkrete situation, respondenten aktuelt befinder sig i. Blandt besvarelserne fra ansatte på de centrale e-læringsenheder er der således en tendens til at lægge vægt på didaktiske aspekter men i nogle tilfælde også på de organisatoriske eller tekniske. Undersøgelsen var særligt målrettet personer med e-læringsansvar på institutionsniveau, og det begrænsede antal besvarelser fra personer med decentral ansættelse giver derfor ikke et klart billede af en gennemsnitlig undervisers syn på e-læring.

Generelt opfattes begrebet e-læring i besvarelserne bredt, fra anvendelsen af IKT-baserede metoder til administration af kurser og studerende, over brugen af kursushjemmesider til at formidle information om undervisningen, og til anvendelsen af IKT- og internetbaserede metoder til aktiv formidling, dialog og refleksion til fremme af læringsprocessen.

Internettets rolle inden for e-læring (fx i form af web-baseret læring) nævnes som hovedregel ikke, men må i de fleste tilfælde antages som implicit.

Det er interessant, at kun en enkelt besvarelse nævner det aspekt ved IKT-støttet og netbaseret undervisning, der generelt rummes under betegnelsen fleksibel læering: Læring, som bl.a. er fleksibel med hensyn til tid og sted for gennemførelse af studieaktiviteterne, individuelt studie-tempo, tilpasning af indhold, valg af metoder under hensyntagen til individuel læringsstil etc. (Collis \& Moonen, 2001; McAleese, 2003; Georgsen \& Bennedsen, 2004). Som det formuleres i den pågældende besvarelse: Internettet giver mulighed for at tilrettelagge undervisningen mere fleksibelt, uafhæengigt af tid og sted, samtidig med at det skaber nye muligheder for at understøtte videns-skabelsesprocessen og samspillet mellem studerende og eksterne interessenter. Derncest giver multimedieteknologier mulighed for at udforme læringsmaterialer (...), der appellerer til flere forskellige intelligenser og lceringsstile, og giver mulighed for at inddrage praksis på nye og innovative måder...”. 


\section{Anvendelser af e-læring}

Det er interessant at se ovenstående definitioner af e-læring i lyset af den faktiske anvendelse af e-læring på de danske universiteter - således som denne tegner sig gennem besvarelserne. Der må naturligvis tages forbehold over for repræsentativiteten af en undersøgelse, der er baseret på relativt få svar, men netop sammenligningen af de enkelte respondenters opfattelse af begrebet e-læring og de muligheder de ser knyttet hertil, med den faktiske anvendelse af elæring i den daglige praksis, giver en vis baggrund for at vurdere potentialer og udviklingstendenser.

Det generelle billede i forbindelse med den traditionelle tilstedeværelsesundervisning er, at de studerende på de fleste institutioner har adgang til ét eller flere e-læringssystemer, der i varierende grad anvendes som støtte for tilstedeværelsesundervisningen, hyppigst som en administrativ ramme om fordeling af materiale til de studerende.

Den faktiske anvendelse af e-læring varierer dog meget. Nogle universiteter (SDU, DPU, DTU, CBS $)^{3}$ lægger vægt på, at de fleste eller alle kurser figurerer i e-læringssystemet, og i nogle tilfælde (SDU) er dette et ledelsesformuleret krav, der dog tilsyneladende ikke opfyldes i alle fag:

- Alle studerende vil dog have oplevet mindst ét fag, der anvender e-læeringsplatformen (SDU).

- Vi formoder, at samtlige aktive studerende bruger platformen (DTU).

- Alle studier benytter platformen til at kommunikere undervisningsrelaterede meddelelser og materialer (CBS).

I andre tilfælde har man været mere tilbageholdende:

- Vi har nok kun ca. 25 kurser ud af mindst 257 udbudte... (RUC).

Eller man er for øjeblikket i en afsøgende eller forberedende fase:

- Vi er i pilotfasen, og kun udvalgte områder lukkes ind i e-læeringssystemet (KVL).

Den mest almindelige anvendelse af e-læringssystemer i de traditionelle uddannelser er knyttet til studieadministration og distribution af materiale:

- ... i grove trcek som elektroniske dueslag, E-støtte som supplement til tilstedeværelsesundervisningen... (KU).

- Ifølge min egen (lceringsbaserede) definition af e-læering anvendes det kun i ringe grad. Hvis man tilføjer, at e-lcering også kan støtte administrative undervisningsformål, anvendes det i rig udstrcekning gennem udsendelse af meddelelser og via fildistribution (DTU).

- Snarere et e-content system end et e-lceringssystem (KVL).

Nytænkning af pædagogiske modeller og muligheden for blended learning eller flexible learning synes generelt ikke fremtrædende i de traditionelle uddannelser, men enkelte eksempler findes dog:

- Introduktionen af CampusNet har fået flere undervisere til at overveje, hvordan IKT kan bruges (DTU).

- Nogle studier eksperimenterer med netbaserede aktiviteter (CBS).

\footnotetext{
${ }^{3}$ Forkortelserne for universitetsnavnene fremgår af Figur 1.
} 
Egentlig fjernundervisning bruges næsten ikke, men også her er der undtagelser:

- E-lcring anvendes i forbindelse med praktikophold under kandidatuddannelsen, hvor de studerende er spredt over hele landet (DFU).

- Fjernundervisning anvendes (kun) på enkelte kurser (DTU).

- Der findes to studier, som kan følges $100 \%$ på nettet (CBS).

Også fra fag til fag findes der betydelige forskelle på grund af forskellige faglige traditioner og arbejdsmetoder:

- Især sprogfagene anvender e-læring i stort omfang, medens tæenkefagene (filosofi, litteratur og religion) ikke bruger det ret meget (SDU).

I forbindelse med master-uddannelser o. lign. spiller e-læring en klart mere fremtrædende rolle:

- Ca. 15 masteruddannelser bruger FirstClass til kurser, projektarbejde og -vejledning, samt til studieadministration. De fleste af vores master-uddannelser, tilrettelagt som åben uddannelse, er baseret på e-lcering/mixed-mode (AAU).

- Åben uddannelse og master-uddannelserne anvender platformen meget (SDU).

- E-læring anvendes i forbindelse med Master of Drug Development (DFU).

- De faglige suppleringskurser kan siges at være egentlig fjernundervisning (SDU).

- Masteruddannelserne bruger i højere grad e-læring i tilrettelcggelsen af undervisningsforløb (DPU).

Det er vanskeligt at se et entydigt mønster ved sammenligning af de gamle med de nye universiteter. IT-Universitetet udgør dog en undtagelse:

- Vi har ikke haft traditioner for undervisning uden e-læring - vi har bare undervist på denne måde siden starten i 1999. Der er to hovedgrupper af e-lcering: Netbaseret undervisning og netstøttet undervisning (som udgør hovedparten) (ITU).

Det er et særkende ved mange af besvarelserne, at respondenterne opfatter indføring og udvikling af e-læring som en fremadskridende proces:

- P.t. ikke scrligt udviklet, men på vej mod noget rigtigt. Gode rammer er ved at blive etableret, modtageligheden blandt VIP, TAP og stud. er stor (KU).

- Vi ville i dag ikke kunne lukke for e-læringsplatformen uden at det ville give ballade. Det kunne vi for ca. 3 år siden (SDU).

- Der er interesse for e-læring, og vil prøve at finde ud af, hvad vi kan bruge det til (DFU).

\section{Anvendelser af e-læringsplatforme}

Figur 1 viser den omtrentlige studenterbestand i 2004, som opgivet på de enkelte universiteters hjemmesider eller i deres årsrapporter. Desuden er anført de forkortelser for universitetsnavnene, som benyttes i denne artikel.

Figur 2 viser hvilke større e-læringsplatforme som benyttes ved de 12 universiteter, og hvilken andel af de studerende der skønnes at bruge dem. Ved nogle universiteter er der modtaget flere svar, og der er foretaget en gennemsnitlig vurdering. Ved udregning foretaget på basis 
af studenterbestande i 2004 svarer de viste procenttal til at ca. 92.500 af de i alt ca. 130.000 studerende (71\%) benytter et større e-læringssystem.

Spørgsmålet omfatter ikke hvor stor en del af undervisningsforløbene, der er støttet af en elæringsplatform, eller i hvilken grad - og heller ikke om systemerne bruges med specielle formål, eller hvorvidt de udgør en afløser for statiske hjemmesider.

Repræsentanter for 11 universiteter (dvs. alle med undtagelse af DFU) deltog 3. november 2005 i et fællesmøde for personer med centralt e-læringsansvar, hvor resultaterne i Figur 2 blev præsenteret, og hvor der var mulighed for at justere og korrigere for evt. fejlbesvarelser.

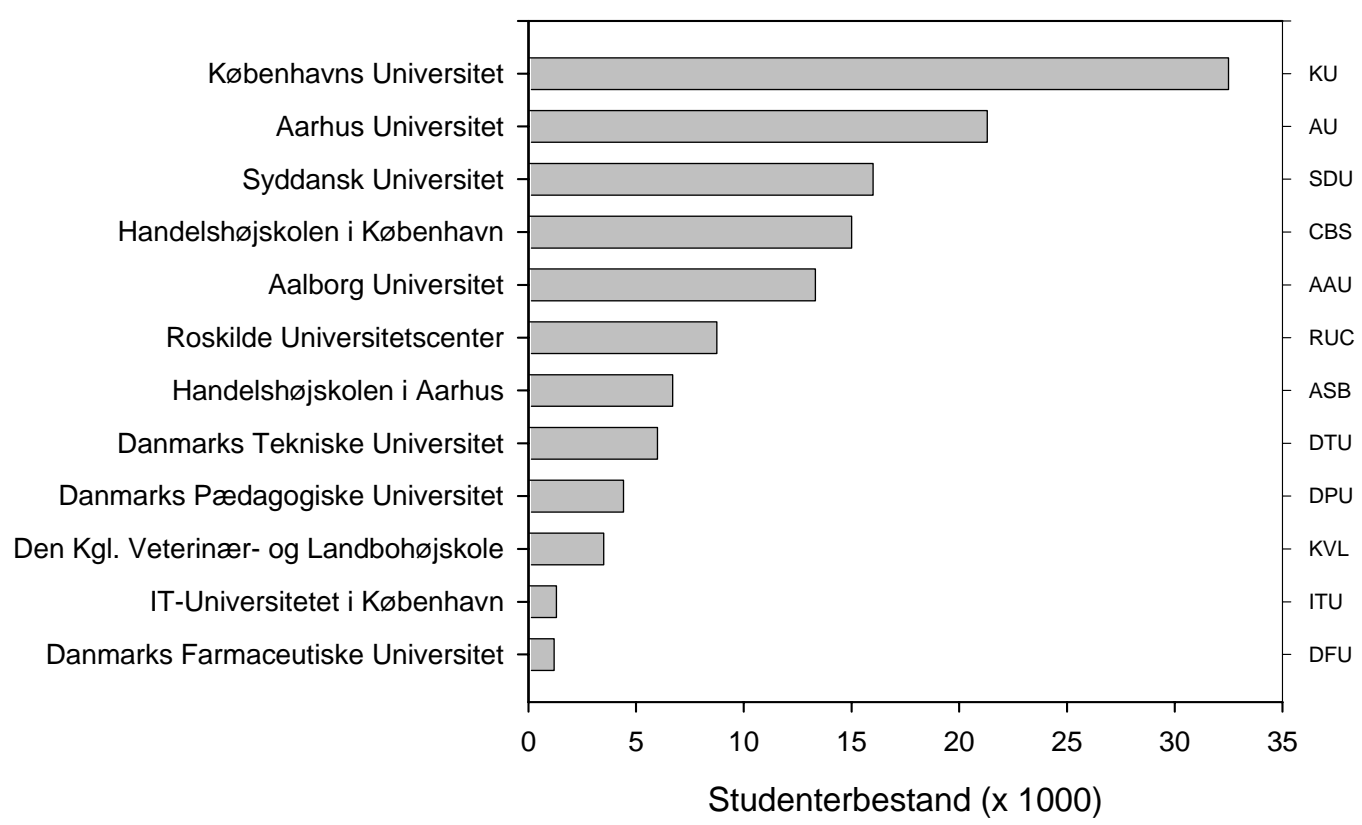

Figur 1. Omtrentlig studenterbestand ved de 12 danske universiteter i 2004.

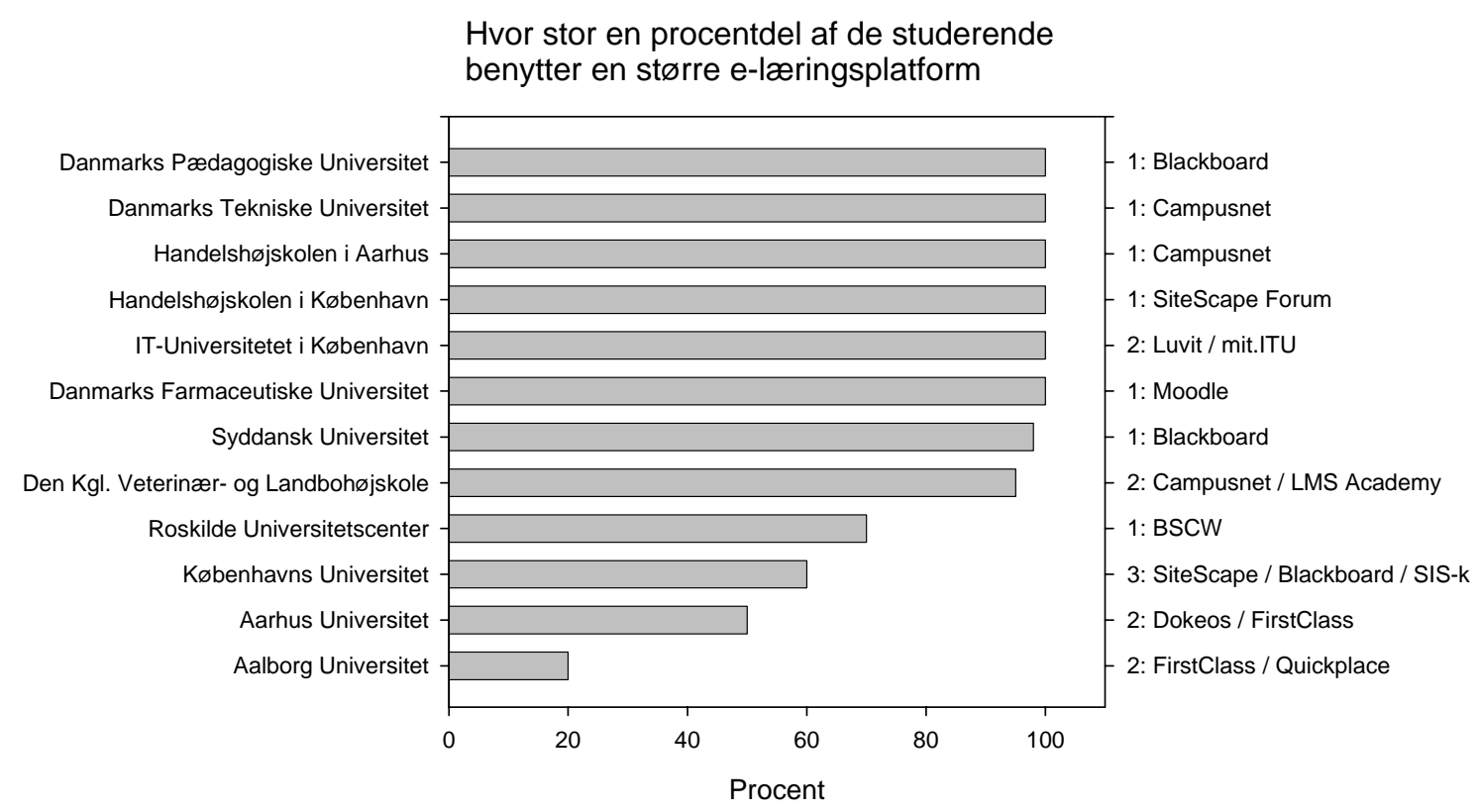

Figur 2. Procentdel af de studerende, som benytter en større e-læringsplatform. 


\section{Beslutningsprocesser for e-læring}

De fleste universiteter synes at have etableret en delvist central struktur omkring indkøb og drift af IKT-systemerne. Halvdelen svarede at beslutningerne var forankret ved universitetets ledelse (SDU, KU, ASB, DTU, DPU, FDU), og i de fleste tilfælde bakket op af et IKT- eller e-læringsudvalg. Derudover angav 4 universiteter (AAU, AU, CBS, RUC), at et centralt IKTudvalg er eller vil blive ansvarligt for beslutningerne. Anskaffelse og drift af IKT-systemer til e-læring kan være forbundet med betydelige omkostninger, og da mange løsninger griber ind i de studieadministrative rutiner, kan det ikke undre at ledelserne har interesse i at sikre, at de valgte løsninger kommer til at gavne så mange ansatte og studerende som muligt.

Ingen af respondenterne angav dog, at beslutningerne er helt centraliserede. Dette skyldes sandsynligvis, at det på nogle universiteter er frivilligt at anvende de centrale e-læringsløsninger. Det kan således være det enkelte fakultet, institut eller studium, der indkøber IKT-systemerne og varetager supporten til e-læring. Svaret kan også skyldes, at beslutningerne omkring den konkrete didaktiske/pædagogiske anvendelse af e-læringsløsningerne sker decentralt, ofte på niveau af den enkelte underviser.

I alle tilfælde synes den etablerede struktur på universiteterne at hænge sammen med, om der er taget en administrativ, teknisk eller pædagogisk indfaldsvinkel til implementeringsprocessen, eller på hvilken måde disse områder er kædet sammen. Seks af universiteterne (AAU, AU, SDU, KVL, CBS, RUC) har etablerede enheder ${ }^{4}$, der beskæftiger sig med e-læring ud fra både en pædagogisk og teknisk synsvinkel, mens e-læring på de øvrige universiteter er forankret i IKT-afdelingen, studieadministrationen eller HR - eller decentralt på fakultets- eller uddannelsesniveau. Tilsvarende angiver halvdelen af svarene i undersøgelsen at driften af elæringsplatformen ligger i en central IKT-afdeling eller er outsourcet til udbyderen, mens de fleste øvrige indikerer at driften varetages i et samarbejde mellem IKT-afdelingerne og pædagogiske koordinatorer, og evt. også administrative supportere.

På de fleste af universiteterne er der etableret en organisation omkring både drift og support af e-læringsplatformene, hvoraf halvdelen fungerer som et samarbejde mellem en central IKTafdeling og en pædagogisk funktion og/eller en e-læringskoordineringsfunktion. Tre universiteter (RUC, KVL og DFU) er i gang med at etablere rammer for drift og support af e-læringsplatforme.

\section{Strategier for indførelse af e-læring}

Otte ud af de tolv universiteter har formuleret en strategi for indførelse og anvendelse af elæring. I de fleste tilfælde er strategipapirerne dog ikke åbent tilgængelige. Det følgende afsnit er derfor baseret på de strategipapirer, der er udgivet på AAU, SDU, KVL og KU og som er tilgængelige på disse universiteters website. Strategierne drejer sig generelt alle om at udnytte IKT til at understøtte læring - specielt med fokus på de studerendes læring - enten gennem pædagogisk fornyelse eller ved at lette de administrative opgaver omkring undervisningen. Et andet aspekt i strategierne består i at positionere universiteterne i forhold til omverdenen som et led i deres "branding”-strategi og image-pleje i forhold til aftagere og kommende studerende.

Ser man nærmere på de strategiske indsatsområder, som de publicerede strategier indeholder, er der også fællestræk her. På det tekniske område satser de 3 af universiteterne på en fælles værktøjskasse og e-læringsplatform for alle universitetets undervisere og studerende. Alle har indsatsområder omkring pædagogiske udviklingsindsatser enten i form af fag- og studieudvik-

\footnotetext{
${ }^{4}$ AAU: Center for IT støttet fjernundervisning, samt E-learning Lab; AU: E-læringsenheden; SDU: elæringskoordinatorerne; KVL: IT Learning Center; CBS: CBS Learning Lab; RUC: UNIpæd).
} 
lingsprojekter eller udvikling af nye eksamens- og undervisningsformer. To af universiteterne har kompetenceudvikling af undervisere og studerende som et vigtigt element. Derudover er der organisatoriske tiltag i form af udvikling af politikker for anvendelse af e-læring, samt inddragelse af eller etablering af nye enheder til at støtte udviklingen.

Undersøgelsens resultater er her nogenlunde på linie med en undersøgelse af e-learning initiativer og modeller på universiteterne i EU foretaget i $2004^{5}$. I rapporten fra sidstnævnte undersøgelse er de europæiske universiteter opdelt i følgende grupper: "The front runners", "the cooperating universities", "the self-sufficient universities" og "the sceptical universities". Halvdelen af universiteterne befandt sig i "sceptical” gruppen, hvor kun få havde formuleret en IT-strategi og hvor IKT-services var begrænsede, samt en stor del af underviserne skeptiske. De øvrige universiteter befandt sig i "cooperating” og "selfsufficient” grupperne, hvor holdningen til IKT i undervisningen overvejende var positiv, halvdelen havde formuleret en strategi for området eller var i gang med det, men udbredelsen af IKT-services var begrænset. Der var ingen "frontrunner” universiteter i Danmark. På baggrund af nærværende undersøgelse kan vi se at de danske universiteter nu er kommet længere med implementering af IKTløsninger og formulering af strategier.

I nærværende undersøgelse har e-læringsansvarlige ved de danske universiteter også svaret på, hvilke forandringer de forventer på e-læringsområdet i de kommende år. Her er svarene primært fokuseret på tekniske forhold. På tre universiteter forventes en konsolidering af elæringssystemerne i retning af centraliserede løsninger, men med flere muligheder og værktøjer end der er tilgængelige i dag. Det kan f.eks. være bedre integration til andre systemer, understøttelse af flere sprog og mere fleksibilitet i anvendelsesmulighederne. På tre andre universiteter forventes en større anvendelse af synkrone kommunikationsværktøjer, herunder brug af video og streaming. De fleste af de øvrige svar beskriver forventninger til organisatoriske tiltag på e-læringsområdet. På fire universiteter nævnes stigende anvendelse af e-læring, herunder gennem øget opmærksomhed om fænomenet. Det fremgår ikke direkte hvordan dette skal ske - om det fx er gennem implementering af strategier og politikker, gennem øget ressourcetilførsel eller etablering af e-læringsorganisationer.

Af øvrige forventninger nævnes øget samarbejde med universiteter over hele verden, muligheden for at tiltrække udenlandske studerende gennem fjernundervisning, samt brug af weblogs og portfolier.

\section{Diskussion: implementering af e-læring}

I sin mest generelle form kan e-læring beskrives som: En fcelles betegnelse for IT-støttet eller IT-baseret lcering (se fx http://www.linqx.dk). Denne definition er så bred, at den inkluderer enhver anvendelse af IKT i undervisningen, hvad enten den tjener til at formidle indhold, fremme kognitive processer, eller danne en organisatorisk eller administrativ ramme om et undervisnings- eller læringsforløb. Selvom der i undersøgelsen var stor spredning i besvarelserne vedrørende definitioner på e-læring, synes de flestes opfattelse dog at kunne rummes af denne brede definition. Der synes også at være en forståelse af e-læring som noget mere omfattende end blot det, der formidles via universiteternes e-læringsplatforme. Platformenes funktioner er på én gang forskellige, men også samtidig ganske sammenlignelige. Mange systemer indeholder nogenlunde tilsvarende funktionalitet. Vi har ikke spurgt om platformenes funktioner i den aktuelle undersøgelse, men med det kendskab vi har til dem, dækker platformene typisk de fælles e-læringsbehov, mens systemer og programmer som er mere målrettede mod specielle e-læringsfunktioner typisk ikke understøttes. Eksempler herpå kunne være

\footnotetext{
${ }^{5}$ Studies in the Context of the E-learning initiative: Virtual Models of European Universities. (Draft Final Report to the EU Commission), Februar 2004. PLS Rambøll Mangement.
} 
video og videokonference, 3D-visualiseringer og simulationer, samt mere avancerede interaktive applikationer.

\section{Faktorer, som vanskeliggør indførelsen af e-læring}

Uden koordinerede visioner og mål, er det vanskeligt at implementere e-læring i en stor organisation. Hvis der således mangler ledelsesmæssig opbakning og dermed også ressourcer, vanskeliggøres implementeringen. Den centrale opbakning får dermed også indflydelse på muligheden for at motivere medarbejderne til at komme i gang. E-læring forudsætter ændring og nytænkning af både undervisningens form og indhold, samt af samarbejdet mellem studerende og undervisere. Der er endnu en del fordomme i undervisningsmiljøerne, som kun kan udfordres, hvis der skabes eksempler på succes med e-læring, og såfremt disse eksempler dokumenteres.

Problemer omkring medarbejdernes IKT-pædagogiske kompetencer bliver af flere nævnt som en barriere. Her peges der på, at der stadig er behov for at udvikle IKT-kompetencerne, således at anvendelsen af IKT i undervisning og administration bliver en hjælp og ikke en hindring. Kobles en manglende interesse for og refleksion over anvendelsen af IKT i undervisningen med autonome og lukkede undervisningsmiljøer, er der grobund for konservatisme og ringe muligheder for nytænkning og udvikling.

\section{Faktorer, som fremmer e-læring. Strategisk forankring $\mathrm{mm}$.}

Flere respondenter peger som nævnt på, at den ledelsesmæssige opbakning har afgørende betydning for, hvordan e-læring kan implementeres. Centrale beslutninger og planer for anvendelse af e-læring kan fremme en åben indstilling hos studienævn, undervisere og administrativt personale, således at e-læring ikke opleves som et diktat, men bliver en integreret del af den måde undervisningen organiseres på. Det bliver således ikke den enkelte undervisers egen beslutning, hvorvidt e-læring skal anvendes, men stillingtagen til hvordan, og i hvilken udstrækning e-læring skal inddrages, kommer til at indgå som en del af studienævnenes drøftelser af studieordninger, pensum og undervisningsplaner. Dermed bliver e-læring heller ikke et område, som blot ildsjæle tager til sig, fordi de ikke kan lade være. Vi skønner dog, at det fortsat er vigtigt at understøtte ildsjælene, fordi de optræder som inspirationskilde for andre. Ildsjæle vil ofte kunne fremvise gode eksempler på anvendelsen af e-læring, og dokumenteret succes har stor betydning i implementeringsprocessen. Dette bliver i undersøgelsen bl.a.

kaldt praktisk demonstreret begejstring. I den forbindelse har ressourcer til forsøg og eksperimenter med e-læring stor betydning. Når disse tiltag knyttes til forskningsmiljøerne, skabes der gode muligheder for ikke kun at lave forsøg og eksperimenter, men også for den efterfølgende dokumentation og udbredelse af erfaringer og resultater.

Flere besvarelser i undersøgelsen fokuser på de pædagogiske behov hos underviserne og de læringsmæssige muligheder hos de studerende, når e-læring skal indarbejdes i studierne. Det er således en væsentlig opgave for medarbejdere i e-læringsenheder at deltage i og støtte drøftelser af, i hvilke pædagogiske sammenhænge e-læring giver mening og har relevans, samt at præsentere e-læringsværktøjer, som bedst understøtter undervisernes forberedelse af undervisningen og de studerendes læring.

God service og support er helt afgørende for mulighederne for oplevet succes. I den forbindelse peges der i svarene på, at både udfarende e-læringsvejledere, medarbejdere fra IT-service, samt det administrative personale er vigtige ressourcepersoner i denne proces. De administrative medarbejdere på studierne skal have en grundig indsigt i e-læringsplatformens funktioner, så de kan være behjælpelige for både studerende og undervisere. For at underviserne kan lære at udnytte platformenes iboende pædagogiske muligheder, er det vigtigt at etablere tilbud om veltilrettelagt og i nogle tilfælde individuel vejledning. Underviserne må have mulighed for 
at deltage i arrangementer, hvor de kan hente inspiration til deres eget arbejde. De skal have noget med hjem! De studerende skal ligeledes modtage en målrettet introduktion, således at de kan indgå som aktive medspillere i udvikling og brug af e-læring.

På en del universiteter arbejdes der meget med at integrere data fra de studieadministrative systemer med e-læringsplatformene, således at underviserne får et minimum af administrative opgaver. Dette betyder samtidig, at de studerende får adgang til oplysninger om de aktuelle fag og kurser på platformen, og at der sker automatiske opdateringer. Flere steder er der etableret single sign on, således at problemerne med flere passwords og koder er afskaffet. På de fleste universiteter er der dog stadig ikke fuld integration mellem systemerne, og der pågår et stort arbejde i denne retning. Flere har arbejdet med at informationer til studerende bliver givet ét centralt sted, og adgangen til både information, materialer og samarbejde er dermed blevet nemmere. Der er således bred enighed om at jo bedre infrastruktur, des bedre implementering og udrulning af de nye systemer.

Universiteternes studiemiljøer, med adgang til både fastnet og trådløse net, har tilskyndet mange studerende til at anskaffe sig bærbare computere. De har derfor også en forventning om, at de nemt og hurtigt vil kunne finde studierelevante materialer og informationer, og de lægger dermed også pres på underviserne for at få de bedste løsninger.

Som det fremgår, er danske universiteter brugere af mange forskellige e-læringsplatforme, men i svarene er der alligevel et vist sammenfald omkring forhold vedr. valg og anvendelse af en e-læringsplatform, der kan fremme e-læring. Følgende forhold bliver nævnt:

- Platformen skal vælges med omhu.

- Der skal være tid både til implementering, vejledning og eksperimenter.

- Platformen skal være let at anvende.

- Der skal være mulighed for at yde god service.

- Mulighed for at undervisere selv kan vælge, om de vil anvende platformen og i hvilket omfang (på dette punkt er der dog ikke helt konsensus!).

Nogenlunde tilsvarende konklusioner fandt man i en undersøgelse af implementering af elæring i det åbne universitet i Holland (Jochems, Merriënboer, \& Koper, 2004; side 183), hvor de nævnte forhold sættes i kontekst og diskuteres yderligere, også i relation til strategiske overvejelser.

Selvom det ikke på baggrund af nærværende undersøgelse endeligt kan konkluderes, hvorvidt adgang til en fælles platform fremmer eller hæmmer brugen af e-læring, peger flere besvarelser dog på, at en fælles platform kan være - eller allerede er - en fremmende faktor.

Udover de nævnte faktorer har følgende forhold betydning for udvikling og fastholdelse af implementeringsprocessen:

- Efterspørgsel efter åben uddannelse fra erhvervslivet.

- De studerende har perioder i studiet, hvor de ikke er på universitetet.

- Desuden skal det være sjovt, spændende og udfordrende at arbejde med e-læring og deltage i udviklingsprocessen.

\section{Internationale perspektiver}

Nærværende undersøgelse har set på implementering af e-læring i et nationalt dansk perspektiv. Der er dog ikke meget som tyder på, at Danmark udgør et særtilfælde, når det gælder implementering af e-læring. Der er foretaget mange undersøgelser af e-læringen på europæiske 
universiteter. Coimbra-gruppen af europæiske universiteter gennemførte således en undersøgelse i 2002 (se resume på http://www.coimbra-group.be/DOCUMENTS/summary.doc). Undersøgelsen vurderede det som meget væsentligt at arbejde for en styrkelse af de pædagogiske aspekter af e-læring, men også for en opgradering af undervisernes IKT kompetencer.

I Storbritannien er gennemført omfattende undersøgelser, ikke mindst i regi af JISC, Joint Information Systems Committee (Se http://www.elearning.ac.uk/) og af UCISA (se http://www.ucisa.ac.uk/groups/tlig/vle/VLEsurvey.pdf). Betegnelsen VLE (Virtual Learning Environment) benyttes i UCISA-undersøgelsen nogenlunde synonymt med e-læringsplatform i nærværende undersøgelse. I år 2001 havde 76\% af britiske universiteter et strategipapir for e-læring og ca. 40\% benyttede en e-læringsplatform. Starten på denne implementering var også i England sket omkring 1998, hvor kun ganske få universiteter benyttede en platform. Engelske universiteter følger den globale udvikling, hvor et klart flertal anvender en af de store platforme på markedet: WebCT, Blackboard, Firstclass, i faldende hyppighed. De vigtigste incitamenter til at arbejde med e-læring var et ønske om øget fleksibilitet og effektivitet i undervisning og læring. Fordelingen af ansvar for beslutningsprocesserne var i England nogenlunde svarende til den, som vi fandt i nærværende undersøgelse: (IT afdelinger: 63\%, Fakulteter: 57\%, Enheder til uddannelsesudvikling: 56\%, administrative IT enheder: 21\%).

Et udpluk af nordiske universiteter er undersøgt i WEB-EDU - Web Education Systems projektet (http://www.nettskolen.com/in_english/webedusite/ ) i 2001 og er refereret i (Paulsen, 2003). Resultaterne viser, i sammenligning med det aktuelle studium, at der i Danmark fra 2001 til 2005 har været en meget kraftig udvikling i anvendelsen af centrale systemer til e-læring ved danske universiteter. I alle de nordiske lande er der sket en udvikling af e-læringssystemer, som siden har opnået en vis udbredelse. Blandt de større systemer findes ClassFronter (Norge), Luvit (Sverige), Oodi (Finland), og Campusnet (Danmark).

Implementeringen af Open-source systemer er sket relativt sent i forhold til de kommercielle systemer og meget tyder på, at vi kun har set begyndelsen af denne udvikling. I Danmark er Open-source systemerne repræsenteret ved Dokeos (www.dokeos.com) ved AU, Moodle (www.moodle.org) ved DFU, samt indledende arbejde med platformen Sakai ved RUC (http://www.sakaiproject.org).

\section{Fremtiden}

Ved danske universiteter markerer 2005 året for oprettelsen af et nationalt netværk for samarbejde imellem centrale e-læringsenheder: Danske Universiteters E-Læringsnetværk. Samarbejdet er kommet i stand som en erkendelse af, at implementering af e-læring udgør sejlads i et nyt og ukendt farvand, og at vi derfor på universiteterne kan have stor glæde af at trække på hinandens erfaringer. Enhederne, som er oprettet indenfor de seneste år, har mange lighedspunkter. De er relativt små og befolket af pionerer, som nok typisk bekymrer sig mere for pædagogiske og organisatoriske spørgsmål end for tekniske. De platform-specifikke forskelle universiteterne imellem ser derfor ikke ud til at kunne få hæmmende betydning for et fremtidigt samarbejde mellem enhederne.

Med en kombination af visioner for fremtiden med ekstrapoleringer fra den aktuelle undersøgelse, mener vi at vi kan have forventninger om, at e-læringen ved danske universiteter i løbet af de nærmeste fem år vil være karakteriseret af at:

- Alle studerende og studieforløb vil være understøttet af en e-læringsplatform.

- Der vil være etableret single sign on, så studenter og undervisere ved hjælp af kun én autentificering vil få adgang til alle universitetets IT systemer. 
- Når de fleste tekniske problemer er løst vil e-læringsenhederne kunne hellige sig arbejdet med at udvikle og understøtte undervisernes IKT-pædagogiske kompetencer og udvikle nye effektive undervisnings- og læringsaktiviteter.

- Der vil være igangsat arbejde mhp. smidig udveksling af information imellem de forskellige e-læringssystemer, som stadig vil være i brug.

- Mange nye spændende IKT pædagogiske forsknings- og udviklingsprojekter vil være i gang både internt og imellem universiteterne.

Det væsentligste aspekt ved anvendelsen af IKT i undervisningen består i at fremme de studerendes læring og deres udbytte af studiet. Anvendelsen af e-læringsredskaber, både i de traditionelle universitetsstudier og inden for efter- og videreuddannelsesområdet, rummer betydelige perspektiver, både for universiteternes måde at formidle viden på, og for de studerendes arbejde med deres fag.

Det bliver spændende at følge, hvilken rolle e-læringen kommer til at spille fremover, når universiteterne skal tilpasse sig deres opgave i det moderne videnssamfund.

\section{Referencer}

Collis, B., \& Moonen, J. (2001). Flexible learning in a digital world. London: Kogan Page.

Georgsen, M., \& Bennedsen, J. (2004). Fleksibel læring og undervisning - erfaringer, konsekvenser og muligheder med IKT. Aalborg Universitetsforlag. http://www.learningnet.dk/fileadmin/filer/pdf_artikler/Fleksibellaeringogundervisningkap1.pdf

Jochems, W., Merriënboer, J., \& Koper, R. (2004). Integrated e-learning. Implications for pedagogy, technology and organization. London: RoutledgeFalmer.

McAleese, R. (2003). Flexible learning in a digital world - experiences and expectations 76 2666. Innovations in Education and Teaching International, 40(3), 310-311.

Paulsen, M. F. (2003). Online education. learning management systems. Global e-learning in a Scandinavian perspective. Bekkestua: NKI forlaget.

Piskurich, G. M. (2003). The AMA handbook of e-learning. effective design, implementation, and technology solutions. New York: Amacom. 